\title{
Scientific impact of the Turkish educational dissertations
}

\author{
Aydın Aslan (iD \\ Selçuk University, Konya, Turkey, aydin.aslan@selcuk.edu.tr \\ Ömer Açıkgöz \\ Social Sciences University of Ankara, Turkey, omeracikgoz63@gmail.com \\ Aslı Günay \\ Social Sciences University of Ankara, Turkey, asli.gunay@asbu.edu.tr
}

Check for updates

\begin{abstract}
This study investigates the impact of the Turkish educational dissertations through the scientific impact criterion dealing with the scientific publications extracted from the dissertations in peer-reviewed indexed journals and their citation counts. 124 dissertations completed in 12 Turkish public universities between 2014 and 2017 were selected through criterion sampling. Authors' websites, ERIC, Google Scholar, Researchgate, ScienceDirect and Web of Science databases were scanned to identify the scientific publications extracted from the dissertations, whereas Google Scholar, Researchgate and Web of Science databases were searched to determine their citation counts. 64 scientific publications were extracted from 124 dissertations, no information was found for 60 dissertations. Furthermore, only 34 of 64 scientific publications were cited and the total number of citations was 115 . Since most of these publications and their citation counts were seen in the low impact factor indexed journals, it can be concluded that the scientific impact of these dissertations is low. Due to the core contributions of the field of education to the other fields, some suggestions were made to increase the scientific impact of the Turkish dissertations in line with the concrete findings of this study.
\end{abstract}

Keywords: Educational PhD dissertation, Impact factor, Qualitative research, Scientific impact criterion

\section{Türkiye’deki eğitim bilimleri doktora tezlerinin bilimsel etkisi}

ÖZ Bu çalışmanın amacı, Türkiye'deki eğitim bilimleri doktora tezlerinin etkisini ilgili tezlerden üretilen bilimsel çalışmaların hakemli dizinli dergilerde yayınlanması ve yayınlanan bu çalışmalara yapılan atıf sayılarını kapsayan bilimsel etki ölçütüyle ortaya çıkarmaktır. Çalışmada Türkiye'deki 12 devlet üniversitesinde 2014-2017 yılları arasında tamamlanan 124 doktora tezi incelenmiştir. Örneklem ölçüt örneklemi yöntemiyle belirlenmiştir. Doktora tezlerinden üretilen bilimsel yayınları belirlemek için tez yazarlarının internet sayfaları, ERIC, Google Scholar, Researchgate, ScienceDirect ve Web of Science veritabanları taranmış olup bu çalışmalara yapılan atıf sayılarını saptamak için Google Scholar, Researchgate ve Web of Science veritabanlarına bakılmıştır. Böylelikle, 124 doktora tezinden 64 bilimsel yayın üretildiği belirlenmiş ve geri kalan 60 teze ilişkin herhangi bir veriye ulaşılamamıştır. Dahası, 64 bilimsel yayından sadece 34'üne atıf yapıldığı tespit edilmiş olup toplam atıf sayısının 115 olduğu görülmüştür. Tezlerden üretilen bilimsel yayınlar ile bu yayınlara yapılan atıfların çoğu etki değeri düşük dizinli dergilerde gerçekleştiği için Türkiye'de eğitim bilimleri alanındaki doktora tezlerinin bilimsel etki değerinin düşük olduğu ortaya konmuştur. Ayrıca, eğitim bilimleri alanının diğer alanlara sağladığı temel katkılarından dolayı Türkiye'de doktora tezlerinin bilimsel etkisini artırmak için bu çalışmanın somut bulguları doğrultusunda çeşitli önerilerde bulunulmuştur.

Anahtar

Sözcükler: Bilimsel etki ölçütü, Eğitim doktora tezi, Etki faktörü, Nitel araştırma

Citation:

Aslan, A., Açıkgöz, Ö., \& Günay, A., (2021). Scientific impact of the Turkish educational dissertations. Turkish Journal of Education, 10(3), 237-250. https://doi.org/10.19128/turje.850728 


\section{INTRODUCTION}

The concepts of competitiveness, globalization, knowledge-based economy and knowledge-based society emerged at the beginning of the 1990s. Since then, education has become a basis for all policies in the world, and all countries have reached a consensus that successful competition of nations depends on building the knowledge-based economy (Organization for Economic Co-operation and Development [OECD], 1996; Sum \& Jessop, 2013). By means of the effects of globalization and knowledge-based economy, global competition has reshaped higher education around the world (Knight, 2008; Rust \& Kim, 2012). In this context, the global university rankings, world-class university and internationalization have become important concepts in higher education system since the early 2000 s.

The development of a knowledge-based economy enabled the Ministers of Education of 29 countries to agree on a common vision for the European Higher Education Area (EHEA) in Bologna in 1999. The aims of this agreement are to promote the competitiveness of higher education in the European region, as well as to improve communication and cooperation within higher education institutions (HEIs) in other regions of the world. It includes the establishment of the European Qualifications Framework (EQF) which is a common European reference framework aiming to make qualifications more understandable and comparable across different countries and systems. 48 countries have been full members of EHEA including Turkey since 2001 (EHEA, 2020; European Centre for the Development of Vocational Training [CEDEFOP], 2020). The Turkish Qualifications Framework (TQF) was published in the numbered 29537 Official Gazette on 19 November 2015 by Vocational Qualifications Authority (VQA) through the contributions of the Ministry of National Education (MoNE), the Council of Higher Education (CoHE), and other stakeholders. TQF was then presented to the European Commission (EC) at the meeting on 29 March, 2017 in Brussels and, as a result of the negotiations, it was approved by the European Commission (EC) (EC, 2020a). Particularly, MoNE and CoHE were asked to define what type of qualifications individuals should have in the domains of knowledge, skill and competency according to the definite criteria taking into account the needs of the business world and the society in Turkey (VQA, 2015). Then, these views were reflected in the TQF document, which was prepared under the coordination of the VQA.

Global competition in higher education has led to the development of many performance indicators such as teaching, research, citations, international outlook, industry income and research output to evaluate the contributions of HEIs to education, qualifications of students and graduates, public service and knowledge-based economies. When these indicators are taken into account, it is seen that one of the most important responsibilities of HEIs is to make contributions to creating a knowledge-based economy and welfare economy by searching and coming up with solutions for the societies' problems at this phase. HEIs make significant contributions to producing new knowledge and expanding the current knowledge through graduate studies, especially doctorate degrees (Doctor of Philosophy $[\mathrm{PhD}]$ ).

A doctorate refers to level 8 in both the EQF and TQF which usually requires four years of study, mostly as a period of research. As far as the knowledge domain is concerned, the graduates are expected to have advanced their systematic knowledge concerning theory, practice, method and techniques in a working or learning area and to analyze them critically. As far as the skill domain is concerned, they are expected to come up with solutions for complicated problems in advanced research and/or innovation and to extend the current knowledge or vocational practice. And finally, in the competency domain, they are expected to show competency in developing new ideas and processes in a working or learning area at an advanced level. In other words, these individuals are expected to be highly qualified in knowledge, skill and competency categories in the working area and to autonomously find solutions for the problems they face in working and learning environments or to come up with the most innovative ideas in these environments (EQF, 2020; TQF, 2020). As indicated by Ziman, (1993) researchers in their PhD experience discovering things. Generally, doctoral programs consist of six main parts: entrance 
qualification exams, courses, doctoral qualification exams, writing a dissertation, dissertation monitoring and oral dissertation exam in Turkey. A dissertation is at the top of a "academic genre ladder" (Swales \& Feak, 2000), and the most important piece of writing for students (Hyland, 2004). It represents not only the final student effort in research but also the finishing polish to graduate; an accumulation of the practical and intellectual qualifications that the doctoral candidates should have to successfully leave doctoral training (Buchanan \& Herubel, 1994). Therefore, the dissertation can naturally be regarded as the most important outcome of doctoral education.

Although the quality of doctoral education is now clearly a high priority for HEIs, determining the quality of doctoral education may be a difficult issue. For example, according to the survey results conducted by the European University Association (EUA), 76\% of HEIs use scientific publications of doctoral candidates as the main indicator for the quality of doctoral education (Hasgall et al., 2019). Scientific publications based on the $\mathrm{PhD}$ dissertations are assumed as one of the main indicators to assess the quality of doctoral programs (Cloete et al., 2015). In addition, the number of citations of the dissertation holder's scientific publications is the other indicator to evaluate the quality of $\mathrm{PhD}$ dissertations (Granovsky et al., 1992). Within this scope, this study tried to evaluate the quality of the Turkish educational dissertations according to their scientific impact factors like the number of scientific publications extracted from them and citation counts. Hence, this study focused on the educational dissertations in the Turkish context as the dissertations demonstrate their holders' training concerning their technical, analytical and writing skills they developed in the doctoral training (Lovitts, 2005). In this regard, the dissertations are expected to have a significant impact on the development of policies and applications in the field of education since they demonstrate the students' potential to function as an independent researcher.

\section{Significance of the Study}

One of the indicators determining the quality of research output is scientific impact value. An author's impact on their field or discipline has commonly been measured using their number of scientific publications and the number of times their scientific publications are cited by other researchers. Nowadays, global performance of HEIs are measured by the world university rankings like The Times Higher Education (THE) World University Ranking, Academic Ranking of World Universities (ARWU) and Quacquarelli Symonds (QS) World University Rankings. As part of their framework, they use "the number of scientific publications (or scientific publications per academic) as a performance indicator to measure research influence. The weight of scientific publications per academic is $6 \%$ in the THE World University Rankings and the number of scientific publications $40 \%$ in the ARWU (THE, 2020; ARWU, 2020). In addition, the weight of citations is $30 \%$ in the THE World University Ranking and citations per academic is $20 \%$ in the QS World University Rankings (THE, 2020; QS, 2020). However, in the top 500 universities in the world, there are only two universities from Turkey in THE World University Rankings and QS World University Rankings (THE, 2019; QS, 2019), and only one university in ARWU (ARWU, 2019). It is observed from the data that the Turkish HEIs encounter a challenge to be among the top universities. Also, the Turkish number of scientific publications was 49.930 and Turkey ranked 18th, but the number of citations per document is 0.58 with a rank of 166 in the world in 2019 (Scimago Journal Rankings [SJR], 2020). This shows that the scientific impact factor and implicit quality of the Turkish scientific publications are very low. Therefore, the Turkish HEIs should increase the quality of their research outputs to become world-class universities as the quality of research outputs has an important role in the performance measurement of the HEIs. In this regard, $\mathrm{PhD}$ dissertations and scientific publications extracted from them constitute a significant source for research outputs of HEIs. Also, the number of times these published works have been cited by researchers globally is important to identify their scientific impact, which shows the researchers' skills in spreading their knowledge, findings and ideas with the scientific world. Thereby, it might be said that the scientific publications based on dissertations and their citation counts as an outcome of the $\mathrm{PhD}$ dissertations affect the university rankings indirectly. 
In this study, the dissertations conducted in the field of education were chosen. The changes in the world like technological development, competitiveness, knowledge-based economy, and shifting workforce demands have caused transformations in the qualifications that students should have to take part in today's world (Levy \& Murnane, 2005; Stewart, 2010; Wilmarth, 2010). Hence, education studies are still one of the core and leading social science disciplines to ensure students to prepare for this new world in the 21 st century. Educational studies on the knowledge, skills, attitudes and behaviors, and competencies of disciplines in the student learning process at all levels are carried out in the field of education.

Within this framework, the field of education needs well-trained and qualified doctoral graduates who are capable of producing scientific outputs to contribute to the development of this area. The $\mathrm{PhD}$ holders in the field of education are supposed to bring empirical, concrete and objective solutions to their societies' educational matters, to enable the human capital with whom they interact to become equipped with knowledge, skill and competency and to play an active role in their societies' economic and social transformations. Another reason why the field of education was chosen is that education is one of the core disciplines in the Turkish higher education system since Turkish academics working in the field of education play an effective role in determining the learning outcomes of the higher education programs during the TQF preparation process (CoHE, 2020a). Besides, they play an active role in the preparation of the curricula in all levels of education to train the human capital within knowledge-based economies and societies' needs.

The literature review indicate that several studies have been conducted to evaluate the dissertations in the field of education at the national (Kozikoğlu \& Senemoğlu, 2015; Yağan, 2018; Yetkiner et al., 2019) and international levels (Alves et al., 2012; Kousha \& Thelwall, 2019; Richards et al., 2016). 121 Turkish $\mathrm{PhD}$ dissertations published in the field of education between 2009 and 2014 were examined according to some variables such as higher education institutions, year, research topic, method and research design through content analysis by Kozikoğlu and Senemoğlu (2015). While Yağan (2018) evaluated dissertations based on the perceptions of students and faculty members, Yetkiner et al. (2019) used research subjects, universities, research design, research methods, sample size, data collection tools and education level variables to examine the dissertations. On the other hand, Alves et al. (2012) examined the educational research and doctoral dissertations - in terms of the status of the educational research, the thematic trends, affiliated scientific domains, conceptual frames and methodological approaches in their meta-analytic study. Moreover, Richards et al. (2016) studied the historical trends in counselors for the field of education dissertations. Apart from these studies, Kousha and Thelwall (2019) assessed the impacts of dissertations through the citations derived from Google Scholar and Mendeley. It is understood from the literature review that there is a preference to evaluate the dissertations according to definite variables. It can be deduced from the studies conducted at the national level that the wide impact of the dissertations in the field of education has not been evaluated yet. Hence, this study can be considered to be filling this gap in this area. This criterion deals with the scientific publication extracted from the dissertations in peer-reviewed indexed journals and their citation counts. Therefore, the analysis made here differs from the other studies in terms of the data set and the evaluations of the dissertations with regard to the data source.

It is important to note that the current study is expected to make a significant contribution to the field by identifying to what extent $\mathrm{PhD}$ holders in the field of education are competent to expand the knowledge in their fields in line with the scientific impact criterion. The scientific impacts of the PhD dissertations are thought to enable decision-makers and researchers to improve the doctorate program in education studies in Turkey. This study aims to investigate the scientific impacts of the Turkish educational dissertations through the number of scientific publications extracted from dissertations and their citation counts. Therefore, the findings of this study can shed light on the quality of doctoral education in the field of education in Turkey. 


\section{METHOD}

The research questions of this study were examined through document analysis, which involves reviewing or evaluating documents systematically (Bowen, 2009). It was employed to analyze the educational dissertations conducted between 2014 and 2017.

Criterion sampling, which is a type of purposeful sampling, was used to determine the universities in this study. This sampling is conducted to obtain a comprehensive understanding of the studies meeting definite pre-determined criteria (Suri, 2011). In this context, only one university is selected in each regions of Turkey according to the following criteria: the number of the students studying in the doctoral programs, the number of doctoral program graduates, the number of academics working at the higher education institutions and the number of the publications per academic in national and international indexed journals (CoHE, 2018a). The HEIs with the highest value for these selected criteria in their regions were chosen. Turkey has 12 Nomenclature of Territorial Units for Statistics-1 (NUTS-1) regions which was defined by the European Office for Statistics (EUROSTAT) to apply a common statistical standard across the European Union (EC, 2020b). Also, all selected HEIs are public HEIs established in and before 1992, and also the language of instruction in these HEIs is Turkish to ensure homogeneity between the HEIs. As a result, 12 Turkish public HEIs were selected for this study according to the above criteria and their names are displayed in Table 1. The population of this study consists of 742 dissertations produced in the field of education of these HEIs. As seen in Table 1, 534 dissertations (71.9\%) are open access, whereas $208(28.1 \%)$ are non-open access. In other words, it was identified that about one-third of the dissertations are restricted to other researchers' use.

Table 1.

The Number of Dissertations

\begin{tabular}{llll}
\hline \multicolumn{1}{c}{ HEls } & \multicolumn{2}{c}{ Dissertations in the field of education } \\
& $\begin{array}{l}\text { Open-access } \\
\text { dissertations }\end{array}$ & $\begin{array}{l}\text { Non-open } \\
\text { access } \\
\text { dissertations }\end{array}$ & $\begin{array}{l}\text { Total } \\
\text { number of } \\
\text { dissertations }\end{array}$ \\
Ankara University & 66 & 81 & 147 \\
Atatürk University & 138 & 33 & 171 \\
Çanakkale Onsekiz Mart University & 44 & 13 & 57 \\
Çukurova University* & 56 & 5 & 61 \\
Dokuz Eylul University & 33 & 9 & 42 \\
Erciyes University & 2 & 1 & 3 \\
Gaziantep University & 29 & 5 & 34 \\
Inonu University & 36 & 21 & 57 \\
Istanbul University & 20 & 8 & 28 \\
Karadeniz Technical University & 58 & 12 & 70 \\
Ondokuz Mayis University & 39 & 12 & 51 \\
Uludag University & 13 & 8 & 21 \\
Total & 534 (\%71.9) & 208 (\%28.1) & 742 \\
\hline
\end{tabular}

* Graduate studies in the field of education are conducted by the Educational Sciences Institution, except for Cukurova University, where they are conducted by the Social Sciences Institution.

A fixed number of dissertations, namely three dissertations from each of the HEIs in this study were randomly selected from 2014, 2015, 2016, and 2017. The study group of the dissertations is indicated in Table 2. But since the number of open-access dissertations from Uludag University, Istanbul University and Erciyes University were very low, the total number of the dissertations in these HEIs failed to reach 12 between 2014 and 2017, unlike other HEIs. Therefore, a total of 124 dissertations were included in this study. 
Table 2.

The Dissertations Included in the Study

\begin{tabular}{ll}
\hline HEIs & Number of the dissertations \\
\hline Ankara University & 12 \\
Atatürk University & 12 \\
Canakkale Onsekiz Mart University & 12 \\
Çukurova University & 12 \\
Dokuz Eylul University & 12 \\
Erciyes University & 2 \\
Gaziantep University & 11 \\
Inonu University & 12 \\
Istanbul University & 7 \\
Karadeniz Technical University & 12 \\
Ondokuz Mayis University & 12 \\
Uludag University & 8 \\
Total & 124 \\
\hline
\end{tabular}

\section{Data Collection and Analysis}

The doctoral dissertations produced in the field of education from 2014 to 2017 were accessed through document analysis. This period was chosen to determine the scientific impacts of the dissertations because it could take a long time to produce the scientific publications extracted from the dissertations in the scientific peer-reviewed journals.

Data coding was conducted in three stages. In the first stage, the dissertations in the study group were accessed through the database of the CoHE Thesis Center. The dissertation numbers, author names, the publication year of the dissertations, their names, and their accessibility were recorded in Microsoft Excel Office Program. Secondly, the dissertations which are open access were saved in the office program, and finally, the coding was implemented according to the main themes and results of the dissertations. As the dissertations in the study group of this research are open access, any consent was not received from the dissertations' authors.

Moreover, authors' websites, Education Resources Information Center, Google Scholar, Researchgate, ScienceDirect and Web of Science databases were scanned to identify whether the scientific publications extracted from the dissertations were published in the indexed journals. Their citation counts were searched in Google Scholar, Researchgate and Web of Science databases. Since not every scientific publication can be found in Web of Science database, the ones in Google Scholar and Researchgate ones were selected to comprehensively and thoroughly reach their citation counts. The scientific impact of the educational dissertations conducted in Turkey was evaluated through these two selected research outcomes criteria.

This study also used the indexed criteria for the application of associate professorship in the field of education determined by the Interuniversity Council (IUC) in Turkey to identify the scientific impact value of the indexed journals (IUC, 2018). According to this, the publications indexed in Social Sciences Citation Index (SSCI), Science Citation Index (SCI), Science Citation Index Expanded (SCI-Expanded), Arts and Humanities Citation Index (ACHI) and Emerging Sources Citation Index (ESCI) are accepted as the first order indexes since they are accredited as the most prestigious ones according to their impact factor values in the science world. Secondly, international publications indexed in Education Resources Information Center (ERIC), EBSCO Information Services (EBSCO), Directory of Open Access Journals (DOAJ) and Index Copernicus have lower impact factor values compared with the ones in the first order, labeled second order indexes. Lastly, the impact factor values of national publications indexed in the Turkish Academic Network and Information Center (ULAKBIM), Social Science Citation Index (SOBIAD) and Turkish Education Index fall behind the ones in both the first and second orders namely, third order indexes. 


\section{Validity and Reliability}

The methods used in data collection and analyses have increased the reliability of the current study. The dissertations can be accessed through the CoHE Thesis Center's database, which also increases the reliability of the study. Besides, the use of the journal classification determined by IUC to identify the scientific impact value of the academic studies -contributes to the reliability of the study.

The validity of the research was ensured in two ways. The first validity was conducted according to the consistency among the main themes and results codes. The second validity, namely criterion validity, was implemented considering the scientific publications extracted from the dissertations in the indexed journals and their citation counts. As it is known, in this type of validity, the relationship between scores derived from a measurement instrument and criterion is examined (Ercan \& Kan, 2004).

\section{FINDINGS}

To determine the scientific impact of the Turkish PhD dissertations, the scientific publications extracted from the dissertations in the national and international indexed journals were firstly determined. The number of these publications was revealed in Table 3.

Table 3.

Number of the Scientific Publications Extracted from the Dissertations in Indexed Journal

\begin{tabular}{ll}
\hline Indexes & Number of scientific publications \\
\hline SSCI, SCI, SCI-Expanded, ACHI, ESCI & 6 \\
ERIC, EBSCO, DOAJ, Index Copernicus & 27 \\
ULAKBIM, SOBIAD, Turkish Education Index & 29 \\
Google Scholar & 1 \\
Book section & 1 \\
Total & 64 \\
\hline
\end{tabular}

As seen in Table 3, six publications in SSCI, SCI, SCI-Expanded, ACHI and ESCI indexed journals were found. There were 27 publications in ERIC, EBSCO, DOAJ and Index Copernicus international indexed journals. Also, there were 29 publications in ULAKBIM, SOBIAD, and Turkish Education national indexed journals. Besides, there was only 1 publication in Google Scholar indexed journal. In addition, it was observed that one of these dissertations was published as a section in an international book. Based on the data set, it appears that the majority of the scientific publications extracted from the dissertations were published in the low impact factor journals compared with the first order journals like SSCI, SCI, SCI-Expanded, ACHI and ESCI indexed journals. Hence, only 64 of 124 Turkish educational dissertations produced scientific publications and the number of scientific publications extracted from them was also 64. For 60 educational dissertations, there was no information about whether scientific publications were extracted from them. Furthermore, no information was encountered in the related databases. In other words, the number of publications per dissertation is approximately 0.5 in the field of education.

Moreover, Table 4 displays the number of the dissertations and scientific publications by universities. It is understood that there are significant differences among the universities with regard to the number of the publications extracted from the dissertations. Half of the 12 universities have six to eight scientific publications extracted from the dissertations in the field of education, while the other half has fewer scientific publications under five. In addition, it seems that universities have better publication performance in the second order and third order indexed journals in the field of education. 
Table 4.

Distribution of Dissertations by Universities and Indexes

\begin{tabular}{|c|c|c|c|c|c|c|}
\hline \multirow[t]{2}{*}{ HEIs } & \multirow[b]{2}{*}{$\begin{array}{l}\text { Number of } \\
\text { the } \\
\text { publications } \\
\text { extracted } \\
\text { from the } \\
\text { dissertations }\end{array}$} & \multicolumn{5}{|c|}{ Indexes } \\
\hline & & $\begin{array}{l}1^{\text {st }} \text { order } \\
\text { indexed } \\
\text { journals } \\
\text { (SSCI, SCI, } \\
\text { SCI- } \\
\text { Expanded, } \\
\text { ACHI and } \\
\text { ESCI) }\end{array}$ & $\begin{array}{l}2^{\text {nd }} \text { order } \\
\text { international } \\
\text { indexed } \\
\text { journals } \\
\text { (ERIC, } \\
\text { EBSCO, } \\
\text { DOAJ and } \\
\text { Index } \\
\text { Copernicus) }\end{array}$ & $\begin{array}{l}3^{\text {rd }} \text { order } \\
\text { national } \\
\text { indexed } \\
\text { journals } \\
\text { (ULAKBIM, } \\
\text { SOBIAD } \\
\text { and Turkish } \\
\text { Education } \\
\text { Index) }\end{array}$ & $\begin{array}{l}\text { Google } \\
\text { Scholar }\end{array}$ & $\begin{array}{l}\text { Book } \\
\text { Section }\end{array}$ \\
\hline Ankara University & 8 & 3 & 2 & 3 & - & - \\
\hline Atatürk Univeristy & 8 & - & 4 & 4 & - & - \\
\hline $\begin{array}{l}\text { Canakkale Onsekiz } \\
\text { Mart University }\end{array}$ & 7 & - & 5 & 2 & - & - \\
\hline Çukurova University & 8 & 1 & 1 & 6 & & \\
\hline $\begin{array}{l}\text { Dokuz Eylul } \\
\text { University }\end{array}$ & 3 & 1 & - & 2 & - & - \\
\hline Erciyes University & 1 & - & - & 1 & - & - \\
\hline Gaziantep University & 8 & 1 & 4 & 3 & - & - \\
\hline Inonu University & 6 & - & 3 & 3 & - & - \\
\hline Istanbul University & 4 & - & 2 & 1 & 1 & - \\
\hline $\begin{array}{l}\text { Karadeniz Technical } \\
\text { University }\end{array}$ & 3 & - & 1 & 2 & - & - \\
\hline $\begin{array}{l}\text { Ondokuz Mayis } \\
\text { University }\end{array}$ & 4 & - & 3 & 1 & - & - \\
\hline Uludag University & 4 & - & 2 & 1 & - & 1 \\
\hline Total & 64 & 6 & 27 & 29 & 1 & 1 \\
\hline
\end{tabular}

The citation counts for these scientific publications according to the indexed journals are listed in Table 5. Table 5 indicates that only 34 scientific publications out of 64 received citations and the total number of citations was 115 . However, it is also observed that the dissertations were mostly cited in low impact factor indexed journals. The number of citations received by the scientific publications extracted from the dissertations in the first order indexed journals (SSCI, SCI, SCI-Expanded, ACHI and ESCI) was 13. There were 62 citations received from publications in the second order international indexed journals (ERIC, EBSCO, DOAJ and Index Copernicus) and 40 citations received from publications in third order national indexed journals (ULAKBIM, SOBIAD and Turkish Education Index). Hence, this result implied that the scientific impact of the dissertations in the field of education is very low in Turkey.

Table 5.

The Citation Counts of the Scientific Publications Extracted from the Dissertations

\begin{tabular}{lll}
$\begin{array}{l}\text { Dissertation } \\
\text { number }\end{array}$ & Publications in the indexed journals & $\begin{array}{l}\text { Number of } \\
\text { citation } \\
\text { counts }\end{array}$ \\
\hline 1 & SSCI & 6 \\
2 & ULAKBIM & 1 \\
8 & ULAKBIM & 10 \\
13 & ULAKBIM & 10 \\
15 & ERIC & 5 \\
16 & ULAKBIM & 1 \\
20 & EBSCHO & 2 \\
22 & ERIC & 6 \\
30 & EBSCHO & 2 \\
34 & EURASIAN SCIENTIFIC JOURNAL & 12 \\
35 & INDEX & 4 \\
\hline
\end{tabular}


Table 5. (Continued)

The Citation Counts of the Scientific Publications Extracted from the Dissertations

\begin{tabular}{lll}
$\begin{array}{l}\text { Dissertation } \\
\text { number }\end{array}$ & Publications in the indexed journals & $\begin{array}{l}\text { Number } \\
\text { citation } \\
\text { counts }\end{array}$ \\
\hline 36 & ERIC & 8 \\
38 & ULKABIM & 1 \\
39 & SOBIAD & 1 \\
40 & ERIC & 4 \\
45 & INTERNATIONAL SCIENCE INDEX & 2 \\
46 & ULAKBIM & 2 \\
48 & ULAKBIM & 1 \\
49 & ULAKBIM & 1 \\
52 & ERIC & 2 \\
55 & INDEX COPERNICUS & 4 \\
56 & EBSCO & 1 \\
59 & EBSCO & 1 \\
63 & ULAKBIM & 1 \\
66 & TURKISH EDUCATION INDEX & 9 \\
69 & ESCI & 2 \\
85 & EBSCO & 2 \\
90 & EBSCO & 1 \\
101 & ULAKBIM & 4 \\
104 & EBSCO & 1 \\
113 & ULAKBIM & 5 \\
114 & DOAJ & 1 \\
120 & SSCI & 1 \\
121 & ULAKBIM & 115 \\
Total & 34 Scientific publications & \\
\hline & & \\
\hline
\end{tabular}

\section{DISCUSSION AND CONCLUSION}

124 educational dissertations conducted at 12 public universities in Turkey from 2014 to 2017 were examined according to the scientific impact criterion, which was evaluated through the number of scientific publications extracted from dissertations and their citation counts. Firstly, the findings showed that about one-third of the dissertations were not accessible to other researchers. In this context, the CoHE prepare the regulation in reference to the numbered 2547 and dated 2 November 1981 law of higher education, to remove a number of the limitations to make theses and dissertations accessible (2018b). In this way, it has been aimed that relevant people can benefit more from these studies.

Secondly, the findings displayed that 64 scientific publications were extracted from $124 \mathrm{PhD}$ dissertations. In other words, the number of publications per dissertation is about 0.5 in the field of education. Besides, the number of scientific publications extracted from the educational dissertations varied among the universities between one and eight. Only 34 of them received citations and the total number of citations was 115 . Also, no scientific publication was encountered for the remaining 60 dissertations. Thirdly, the evaluation of the dissertations showed that the number of scientific publications extracted from the dissertations in the high impact factor journals (SSCI, SCI, SCIExpanded, ACHI and ESCI) was only six. While 27 of them were in international low impact factor indexed journals (ERIC, EBSCO, DOAJ and Index Copernicus), and 29 in national low impact factor indexed journals (ULAKBIM, SOBIAD and Turkish Education Index). Moreover, the distribution of 115 citations made from 34 scientific publications was as follows: 13 in high impact factor journals (SSCI, SCI, SCI-Expanded, ACHI and ESCI), 62 in international low impact factors indexed journals (ERIC, EBSCO, DOAJ and Index Copernicus), and 40 in national low impact factors indexed journals (ULAKBIM, SOBIAD and Turkish Education Index). 
Therefore, it was observed that the scientific publications extracted from the Turkish educational dissertations in high impact factor journals are very low when compared with the publications in international and national low impact factor indexed journals. Briefly, it can be concluded that the scientific impact of publications extracted from the $\mathrm{PhD}$ dissertations in the field of education and their citation counts are low in Turkey. This result might also be interpreted as the quality of doctoral programs in the field of education in Turkey is not at a sufficient level. Nevertheless, it is important to note that the language of all selected higher education institutions are Turkish in this study. This might be one of the reasons why the number of scientific publications and citations counts were low since the language of many high impact journals is English. In fact, $\mathrm{PhD}$ students enroll in their doctoral programs on a competitive basis, get several courses in their fields, take a Doctoral Qualifying Exam and prepare their dissertations under the supervision of their advisors and dissertation monitoring committee. It is understood that these factors fall short of enabling $\mathrm{PhD}$ students to produce theoretical and applied knowledge. Therefore, some improvements should be made in the doctoral training programs.

Besides, the total number of Turkish scientific publications in the field of education was 1.809 and Turkey ranked $11^{\text {th }}$ with respect to the number of scientific publication in this field in 2019. Also, the number of citations per document in the field of education was 0.27 , with a rank of 98 in the world. In addition, total number of scientific publications in the field of education was 6.085 in United Kingdom (UK), 3.792 in China and 2.526 in Germany. Moreover, the number of citations per document in the field of education was 0.56 in UK, 0.55 in Germany and 0.48 in China (SJR, 2020). On the other side, scientific publications conducted in the field of education were indexed in the Web of Science database in 2019 are 1.277, 1.536, 4.301 and 3.399 and the average citations per document was $0.79,1.22,1.3$ and 1.02 in Turkey, Germany, UK and China, respectively (Web of Science, 2020). Thus, the findings of this study are in line with this general picture and indicated that Turkey has no problem with the scientific publications in the field of education quantitatively. But there is a significant challenge for Turkey to compete with international academia in the field of education, particularly in increasing the scientific impact of its research output like citations.

In addition, the findings are also in alignment with the ones articulated in the general report for tracking and evaluation criteria for the Turkish universities prepared by the CoHE (2020b). In this report, the mean of the publications per academic is 0.055 in national indexed peer-reviewed journals and 0.314 in international indexed peer-reviewed journals. Furthermore, when the Turkish HEIs with the number of cited publications in the top $10 \%$ are considered, it is observed that the number of HEIs citations count over 100 is 47. It seems crucial to make it a requirement for the doctoral candidates to publish at least one article in journals with a high impact factor in all Turkish universities for their graduation. This might play a significant role in training better qualified candidates who will work in academia. When the professions of people who completed their $\mathrm{PhD}$ were examined, it was revealed that out of 124 people, 82 of them work as academics at HEIs. While 21 of them are employed as a psychological counselor, 17 of them are employed as a teacher. In addition, three of them work as an expert and one as a public institute administrator.

\section{Limitations}

Some limitations have to be kept in mind when the findings derived from this study were evaluated. Especially the number of HEIs and the number of dissertations had to be limited due to the accessibility of the dissertations. Therefore, making comparison between HEIs according to their scientific publication performance extracted from the dissertations might not be an appropriate approach since the number of dissertations examined was not the same. The search for the number of the published scientific publications extracted from the dissertations, and their citation counts were limited with Education Resources Information Center, Google Scholar, Researchgate, ScienceDirect and Web of Science databases. Owing to the indexed criteria for the application of associate professorship in the field of education determined by the Interuniversity Council (IUC) in this study, Scopus indexing database was not taken into account in this study. It is also important to note that it takes time for publications to be cited. 


\section{Implications}

In line with the findings obtained from this study, the following suggestions might be made for the researchers and the decision-makers in the field of education in Turkey. Firstly, the method used in this study can be applied to non-open access dissertations, non-profit foundation universities, other fields of sciences such as social sciences, natural sciences and health sciences or problem areas can be chosen as a dissertation topic in primary issues. Besides, some regulations can be made to increase the quality and scientific impact value of the Turkish PhD dissertations. Currently, students at some Turkish HEIs have to publish at least one scientific publication extracted from their dissertations as a graduation requirement. Hence, this regulation might be compulsory for all $\mathrm{PhD}$ students and applied at all HEIs in Turkey. Further, at least one scientific publication in a journal with a high impact factor might be required from all doctoral students to graduate from their program or the issues with a high economic and social added-value might be chosen as a topic in doctoral research. Hence, these factors might be envisioned to increase the visibility of the Turkish HEIs in the world university rankings. Moreover, the effectiveness of the doctoral training program in the field of education should be redesigned to train the researchers to produce their dissertations with a high scientific impact.

In sum, the concrete problems which negatively affect the quality of education in Turkish education system should be determined in cooperation with the HEIs and the MoNE. It is also necessary to create a shared study database. The problem areas from this database should be encouraged to be studied in a doctoral study to compete in knowledge-based economies and societies.

\section{REFERENCES}

Alves, M. G., Azevedo, N. R., \& Gonçalves, T. N. R. (2012). Educational research and doctoral dissertations: a review within a research community. Qualitative Inquiry, 18(7), 626-637. https://doi.org/10.1177/1077800412450156

Academic Ranking of World Universities. (2019). Ranking universities in the world. http://www.shanghairanking.com/ARWU

Academic Ranking of World Universities. (2020). Academic Ranking of World Universities: Methodology. http://www.shanghairanking.com/arwu-methodology-2011.html\#2.

Bowen, G. (2009). Document analysis as a qualitative research method. Qualitative Research Journal, 9(2), 2740. https://doi.org/ 10.3316/QRJ0902027

Buchanan, A. L., \& Herubel, J.-P. V. M. (1994). Profiling PhD Dissertation Bibliographies. Behavioral \& Social Sciences Librarian, 13(1), 1-10. https://doi.org/10.1300/J103v13n01_01

Cloete, N., Mouton, J., \& Sheppard, C. (2015). Doctoral education in South Africa. Cape Town: African Minds. Council of Higher Education. (2018a). National thesis center. https://tez.yok.gov.tr/.

Council of Higher Education. (2018b). 2017-2018 statistics for the higher education. https://istatistik.yok.gov.tr/.

Council of Higher Education. (2018c). Regulations to collect, arrange and making graduate theses electronically. https://tez.yok.gov.tr/UlusalTezMerkezi/dosyalar/kilavuz.pdf

Council of Higher Education. (2020a). Turkish higher education qualifications. http://www.tyyc.yok.gov.tr/?pid=23

Council of Higher Education. (2020b). The general report for the tracking and evaluation criteria for the Turkish universities 2019. Ankara University Publishing.

European Centre for the Development of Vocational Training. (2020). European qualification framework. https://www.cedefop.europa.eu/en/events-and-projects/projects/european-qualifications-framework-eqf

European Commission. (2020a). National qualifications framework. https://eacea.ec.europa.eu/nationalpolicies/eurydice/content/national-qualifications-framework-103_en

European Commision (2020b). Eurostat. Retrieved from https://ec.europa.eu/eurostat/web/nuts/background

European Higher Education Area. (2020). European higher education area and Bologna process. http://www.ehea.info/pid34244/ehea.html

European Qualifications Framework. (2020). European qualifications framework. https://ec.europa.eu/ploteus/content/descriptors-page

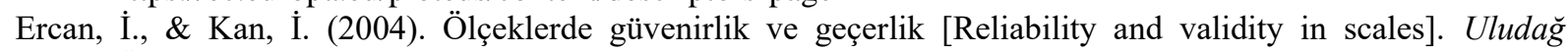
Üniversitesi Tip Fakültesi Dergisi, 30(3), 211-216. 
Granovsky, Y. V., Luibimova, T. N., Murashova, T. I., \& Myatlev, V. D. (1992). Information-based evaluation of the quality of doctoral theses. Scientometrics, 23(3), 361-376.

Hasgall, A., Saenen, B., \& Borrell-Damian, L. (2019). Doctoral education in Europe today: approaches and institutional structures. European University Association.

Hyland, K. (2004). Graduates' gratitude: the generic structure of dissertation acknowledgements. English for Specific Purposes, 23, 303-324. https://doi.org/10.1016/S0889-4906(03)00051-6

Knight, J. (2008). Higher Education in Turmoil: The Changing World of Internationalization. Sense Publisher.

Kousha, K., \& Thelwall, M. (2019). Can Google Scholar and Mendeley help to assess the scholarly impacts of dissertations? Journal of Informetrics, 13(2), 467-484. https://doi.org/10.1016/J.JOI.2019.02.009

Kozikoğlu, İ. \& Senemoğlu (2015). Eğitim programları ve öğretim alanında yapılan doktora tezlerinin içerik analizi (2009-2014) [The content analysis of dissertations completed in the field of curriculum and instruction (2009-2014)]. Ĕgitim ve Bilim, 40(182), 29-41. https://doi.org/10.15390/EB.2015.4784

Levy, F., \& Murnane, R. J. (2005). The new division of labor how computers are creating the next job market. Princeton University Press.

Lovitts, B. E. (2005). How to grade a dissertation. Academe, 91(6), 18-23.

Organization for Economic Co-operation and Development. (1996). The knowledge-based economy. OECD.

Quacquarelli Symonds World University Ranking. (2019). World University Rankins. https://www.topuniversities.com/university-rankings/world-university-rankings/2019

Quacquarelli Symonds World University Ranking. (2020). THE World University Rankings: Methodology. https://www.topuniversities.com/qs-world-university-rankings/methodology

Richards, J., Dykeman, C., \& Bender, S. (2016). Historical trends in counsellor education dissertations. British Journal of Guidance \& Counselling, 44(5), 550-561. https://doi.org/10.1080/03069885.2016.1213373

Rust, V. D., \& Kim, S. K. (2012). The global competition in higher education. World Studies in Education, 13(1): 5-20. https://doi.org/10.7459/wse/13.1.02

Scimago Journal Rank. (2020). Social Sciences $\quad$ Country Rank. https://www.scimagojr.com/countryrank.php?category=3304\&region=OECD

Stewart, V. (2010). A classroom as wide as the world. In H. Hayes Jacobs (Ed.), Curriculum 21: Essential Education for a Changing World (pp. 97-114). Association for Supervision and Curriculum Development.

Sum, N.-L., \& Jessop, B. S. (2013). Competitiveness, the knowledge-based economy, and higher education. Journal of the Knowledge Economy, 4(1), 24-44. https://doi.org/10.1007/s13132-012-0121-8

Suri, H. (2011). Purposeful sampling in qualitative research synthesis. Qualitative Research Journal, 11(2), 6375. https://doi.org/10.3316/QRJ1102063

Swales, J., \& Feak, C. (2000). English in today's research world: a writing guide. University of Michigan Press.

The Times Higher Education World University Ranking. (2019). Ranking universities in the world. https://www.timeshighereducation.com/world-university-rankings

The Times Higher Education World University Ranking. (2020). THE World University Rankings 2021: Methodology. https://www.timeshighereducation.com/world-university-rankings/world-universityrankings-2021-methodology

Interuniversity Council. (2018). The basic criteria in the field of the educations. http://www.uak.gov.tr/?q=node/92\#2019M

Vocational Qualifications Authority. (2015). Turkish Qualifications Framework. https://www.myk.gov.tr//TRR/File6.pdf

Web of Science. (2020). Statistics for the Turkish publications and citations in the field of education. https://wcs.webofknowledge.com/RA/analyze.do?product=WOS\&SID

Wilmarth, S. (2010). Five socio-technology trends that change everything in learning and teaching. In H. Hayes Jacobs (Ed.), In Curriculum 21: Essential education for a changing world (pp.80-96). Association for Supervision and Curriculum Development.

Yağan, S. A. (2018). The evaluation of curriculum and instruction doctoral programs. (Unpublished doctoral dissertation), Eskişehir Osmangazi University.

Yetkiner, A., Erdol, T. A., \& Ünlü, Ş. (2019). Content analysis of PhD dissertations on curriculum and evaluation (1996-2017). Erzincan Üniversitesi Eğitim Fakültesi Dergisi, 21(1), 247-269. https://doi.org/10.17556/erziefd.443298

Ziman, J. (1993). Competition undermines creativity. The Times Higher Education Supplement, p.16 


\section{TÜRKÇE GENIŞLETILMIŞ ÖZET}

Yükseköğretim kurumlarının en önemli sorumluluklarından birisi de toplumların sorunlarını araştırıp bu sorunlara ilişkin çözüm yolları araştırarak bilgi odaklı ekonomiye katkıda bulunmaktır. İlgili kurumlar lisansüstü eğitimle özellikle doktora eğitimiyle yeni bilgilerin üretilmesine ve mevcut bilgi birikiminin artırılmasına önemli katkılarda bulunur.

Doktora eğitiminin en önemli çıktısı doktora adaylarının yazmış oldukları doktora tezleridir. Doktora tezlerinden üretilen bilimsel yayınlar, doktora programlarının niteliklerinin değerlendirilmesinde bir gösterge olarak kullanılabilir. Ayrıca, bu bilimsel yayınlara yapılan atıf sayısı, doktora tezlerinin niteliğinin değerlendirilmesinde başvurulan başka bir göstergedir. Bu çalışmada Türkiye'deki eğitim bilimleri doktora tezlerinin niteliği, tezlerden üretilen yayınların sayısı ve bu yayınlara yapılan atıf sayısı gibi bilimsel etki faktörlerine göre değerlendirilmiştir. Doktora tezleri, doktora öğrencilerinin bağımsız araştırmacı olma potansiyelini gösterdiği için söz konusu tezlerin eğitim bilimleri alanında politika ve uygulamaların geliştirilmesinde önemli bir etkiye sahip olması öngörülmektedir. Bu yüzden, bu çalışma sonuçlarının eğitim bilimleri doktora tezlerinin niteliğine dair bir fikir vermesi beklenmektedir.

$\mathrm{Bu}$ çalışmada doktora tezlerinin bilimsel etkisini değerlendirmek için nitel araştırma yöntemlerinden doküman analizi kullanılmıştır. Çalışmanın örnekleminin belirlenmesinde ölçüt örneklem dikkate alınmıştır. Bu bağlamda Türkiye'nin her bölgesinden bir üniversitenin çalışmaya dâhil edilmesinde doktora programlarında öğrenim gören öğrenci sayısı, doktora programlarından mezun olanların sayısı, yükseköğretim kurumlarında çalışan öğretim elemanı sayısı ile ulusal ve uluslararası dizinli dergilerde öğretim elemanı başına düşen yayın sayısı ölçüt olarak dikkate alınmıştır. Dolayısıyla, 2014-2017 yılları arasında Türkiye'deki 12 devlet üniversitesinde tamamlanan 124 doktora tezi çalışmaya dâhil edilmiştir.

Doktora tezlerinden üretilen bilimsel yayınlarının belirlenmesinde tez yazarlarının internet sayfaları, ERIC, Google Scholar, Researchgate, ScienceDirect ve Web of Science veritabanlarında arama yapılmıştır. Ayrıca, bu bilimsel yayınlara yapılan atıf sayılarını belirlemek için Google Scholar, Researchgate ve Web of Science veritabanlarında tarama gerçekleştirilmiştir.

Veri toplama ve analizinde kullanılan yöntemler, mevcut çalışmanın güvenirliğini artırmaktadır. İncelenen tezlerin YÖK ulusal tez merkezi veri tabanında erişilebilir olması çalışmanın güvenirliğini artıran diğer bir husustur. Ayrıca, Üniversitelerarası Kurul Başkanlığı tarafindan eğitim bilimleri alanındaki doçentlik kriterleri için belirlenen dergi sınıflandırmasının kullanılması da çalışmanın güvenirliğine katkı sunmaktadır. Diğer taraftan, araştırmanın geçerliliğinin sağlanması iki yolla sağlanmıştır. Birinci geçerlilik ana temalar ile sonuç kodları arasındaki uyuma göre gerçekleştirilmiştir. Ölçüt geçerliliği olan ikinci geçerlilik ise doktora tezlerinden üretilen bilimsel yayınların dizinli dergilerde yayınlanması ile bu yayınlara yapılan atıf sayıları dikkate alınarak gerçekleştirilmiştir.

Doktora tezlerinden üretilen bilimsel yayınların hakemli dizinli dergilerde yayınlamasına ilişkin ilgili veri tabanlarında yapılan araştırma neticesinde SSCI, SCI, SCI-Expanded, ACHI ve ESCI dizinli dergilerde toplam 6 yayınının olduğu anlaşılmıştır. ERIC, EBSCO, DOAJ ve Index Copernıcus dizinli dergilerde 27 yayına rastlanılmıştır. ULAKBIM, SOBIAD ve Türk eğitim dizinli dergilerde ise 29 yayının olduğu sonucuna ulaşıııı̧ıtır. Bunlara ek olarak, Google Scholar veritabanında taranan bir dizinli dergide ise 1 yayın olduğu anlaşılmıştır. Böylelikle, 124 doktora tezinden 64 bilimsel yayın üretilmiş olup geri kalan 60 teze ilişkin herhangi bir veriye ulaşılmamıştır. Ayrıca, eğitim bilimleri alanında yapılan doktora tezlerinden üretilen bilimsel yayınların daha çok etki değeri düşük dizinli dergilerde yayınlandığı belirlenmiştir.

Tezlerden üretilen bu bilimsel yayınlara yapılan atıflar incelediğinde 64 bilimsel yayından sadece 34'üne atıf yapıldığı ve toplam atıf sayısının 115 olarak gerçekleştiği görülmüsstür. SSCI, SCI, SCIExpanded, ACHI ve ESCI dizinli dergilerde ilgili yayınlara 13 atıf yapılmıştır. ERIC, EBSCO, DOAJ 
ve Index Copernıcus dizinli dergilerde 62 atıf yapılmasına karşın ULAKBIM, SOBIAD ve Türk eğitim dizinli dergilerde 40 atıf yapılmıştır. Dolayısıyla, eğitim bilimleri doktora tezlerinden üretilen bilimsel yayınlara daha çok etki değeri düşük dizinli dergilerde atıf yapıldığı gözlemlenmiştir.

Sonuç olarak, Türkiye' deki eğitim bilimleri doktora tezlerinden üretilen yayınların bilimsel etkisi ve söz konusu yayınlara yapılan atıf sayısı yüksek değildir. Bu çalışmanın bulguları, eğitim bilimleri alanında doktora eğitiminin niteliğinin düşük olduğunu göstermektedir. Ancak, önemle belirtmek gerekir ki çalışmaya dahil edilen üniversitelerin öğretim dili Türkçedir. Dünya'da etki değeri yüksek birçok derginin dili İngilizce olduğu için bu unsur, ilgili bilimsel yayınların ve atıf sayılarının düşük olmasının nedenlerinden de birisi olabilir. Yine de, doktora öğrencileri rekabetçi bir ortamda doktora programlarına kayıt yaptırırlar, alanlarıyla ilgili çeşitli dersler alırlar, doktora yeterlik sınavına girerler, danışmanlarının denetiminde doktora tezlerini hazırlarlar ve jüri üyelerinin önünde tezlerini savunurlar. Çalışmanın sonuçlarına göre bu unsurların doktora öğrencilerinin kuramsal ve uygulamalı bilginin üretilmesinde yeterince etkin olmadığı anlaşılmaktadır. Bu yüzden, doktora programlarında bazı düzenlemelerin yapılması gerektiği ortadadır.

$\mathrm{Bu}$ çalışma bulguları doğrultusunda eğitim bilimleri alanındaki araştırmacılar ve karar vericiler için bazı önerilerde bulunabilir. Öncelikle, bu çalışmada kullanılan yöntem erişime açık olmayan tezlere, vakıf üniversitelerinde yapılan tezlere ve sağlık bilimleri, sosyal bilimler gibi farklı alanlarda tamamlanan doktora tezlerine uygulanabilir. Doktora tezlerinin bilimsel etkisini ve niteliğini artırmak için bazı düzenlemeler hayata geçirilebilir. Bu kapsamda, doktora öğrencilerinin doktora programından mezun olabilmeleri için etki değeri yüksek bir dergide en az yayın yapma şartı getirilebilir. Tezlerde ekonomik ve sosyal katma değeri yüksek konular doktora araştırmalarında seçilebilir. Dolayısıyla bu faktörlerin, Türk yükseköğretim kurumlarının dünya sıralamasında görünürlüğünü artırması öngörülmektedir. Dahası, eğitim bilimleri alanında doktora programlarının bilimsel etki düzeyi yüksek tezler üretilmesini sağlayacak şekilde yeniden tasarlanması gerekmektedir.

Türk eğitim sisteminde eğitimin niteliğini olumsuz etkileyen somut problemler üniversiteler ve Millî Eğitim Bakanlığı işbirliğinde belirlenmeli ve ortak bir çalışma veri tabanı oluşturulmalıdır. Bilgi tabanlı ekonomi ve toplum çağında diğer ülkelerle yarışmak için doktora çalışmalarında bu veri tabanındaki problemli alanların çalışılması teşvik edilmelidir. 